\title{
The use of geographical and informational systems the provision state and public interests in the implementation of urban development
}

\author{
Yevhen Klushnychenko', Iryna Savchuk² \\ Kyiv National University of Civil Engineering and Architecture \\ Povitroflotskyi avenue 31, Kyiv, Ukraine, 03037 \\ 1 t.klyush@gmail.com, orcid.org/0000-0002-9577-6412 \\ 2 1daisy201221@gmail.com, orcid.org/0000-0002-8688-1413
}

Received 11.04.2020, accepted after revision 17.02.2020

https://doi.org/10.32347/uwt2020.10.1901

\begin{abstract}
The article summarizes that the main problem of forming a modern urban development documentation system consists in direct tendencies of functional-spatial and planning regulation of urban layouts, in the development of the territory with the help of special tools, territorial indicators, and urban planning regulations. Whereas the updated documents should meet new conditions of spatial development of the territory - regulation of socio-economic processes and the architecturalplanning organization of urban planning systems with the help of urban development, including legal regulation of relations between subjects of urban development.

The purpose of the article is to analyse the condition and prospects of using geographical and informational systems in urban planning. A number of scientific methods have been used to achieve this purpose, in particular: analysis, synthesis, generalization, summaries, etc.

Urban development informational content expansion is a trend that characterizes each stage of its development. Under modern socio-economic conditions, the tendency has become a consistency, which, in combination with the managing (regulating) aspect of the modern content of urban development and the improvement of legal relations of subjects of urban development determines the essence of the current stage of urban development.

At present, informational systems are more actively used in Ukrainian urban development rather than in urban development data banks. It has been summarized that due to informational systems, specialists have the opportunity to see, assess, take into account modern processes of the territory development and create the basis for its sustainable spatial development. Informational technologies
\end{abstract}

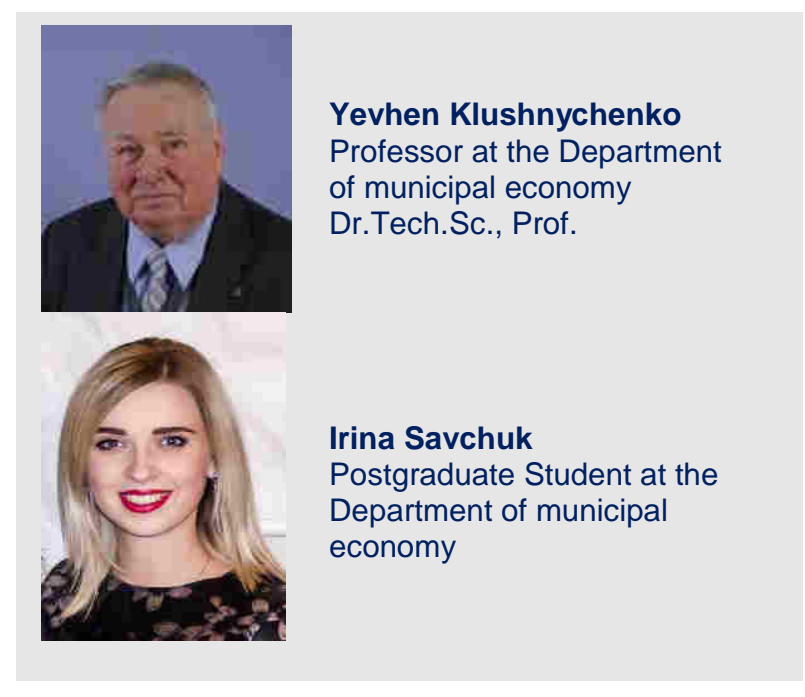

have become an integral part of urban development and have contributed a new organizing and optimizing start, having increased its overall efficiency. A special place in urban development is given to geographical and informational systems (GIS). Their main functions are to create an urban development informational environment, to store territorial cartographical (spatial) information.

It has been generalizes that the use of GIS in urban development involves their specific complex structural application. The information structure of any GIS urban profile is formed on the basis of informational and technological blocks, thematic and informational layers of graphic (cartographical) information, banks and databases.

Key words: urban development, systems of urban development documentation, informational systems, geographical and informational systems. 


\section{INTRODUCTION}

Ukrainian cities and their surroundings developed as new poles of growth and development, forming labour resources, expanding the physical and technological infrastructure, creating a stable and reliable mechanism of landuse regulation, providing a range of proper support services, offering financial incentives and building the capacity of institutions. Cities, especially the largest ones, have formed everything that development cannot do without. Today, in our country, the goals of economic growth increasingly dominate the political agenda, but for successful development, economic growth should proceed in the context of social justice and environmental sustainability.

These problems are associated with many shortcomings in planning system operation. In view of this, the issues that should be addressed to make the spatial development and operation of social and engineering infrastructure systems environmentally sustainable, affordable in economic relations and socially fair, have been highlighted. This builds the dialectic of what the normative goals of Ukrainian urban policy should look like. They require deliberate choice, built on a thorough study of the facts and governed by agreed principles and standards.

Today, the urban development system and set of its principles are set out in a revolutionary document that defines the urban development policy concept at the beginning of the 21st century - 2019-2030 Concept of public administration in urban development. This document is the doctrine and long-term basis of the strategy and tactics of urban development and serves as the fundamental document for improving the urban development of the territory not only for the transition period, but for the entire foreseeable future of the $21 \mathrm{st}$ century. While the formation of a system for serving state and public interests in the implementation of urban development and the regulation of such activities as far as architectural and planning organization of urban planning systems is concerned is considered as the internationalization of the ideas of sustainable spatial development of the territory in the contemporary urban planning policy of Ukraine.

\section{PURPOSE AND METHODS}

The purpose of the article is to analyse the status and prospects of the use of geographical and informational systems in urban planning. To achieve the purpose, a number of methods of scientific knowledge were applied, in particular: analysis, synthesis, generalization, summarization, etc.

\section{RESULTS AND EXPLANATIONS}

The urban planning systems regulation provides for the proper effect from the controllability of the processes of use and development of the territory, which is adequate to the conditions of the existing real estate, land and investments markets. However, an increase in the number of urban development entities, a large-scale expansion of their activity, and a change in legal priorities in their relations greatly complicate serving the state and public interests in the implementation of urban development. Having established the basic principles of the architectural and planning organization of urban development systems, urban science is unable to investigate the managerial relationships between the economic and business activities of urban development entities and the structure of urban development systems, to determine their exact dynamics and development processes without information support. Such difficulties indicate the need to improve and expand the information aspect of the sustainable spatial development of the territory, which will meet state and public interests during the implementation of urban development. Thus, the requirements of contemporary urban planning science and practice, the existing theoretical developments makes it possible to actualize the scientific problem of information support for urban development regulation.

Information support for urban development is actively used in all its existing directions urban (territorial) planning, levelling and building in the territory, architectural and con- 
struction design, creation of urban planning data banks. Its essence lies in working-out and applying urban development informational systems. Up to the present moment, there are legal and technological prerequisites for the implementation of specialized informational systems in order to solve the problems of urban development regulation regarding the architectural and planning organization of urban planning systems (regulation of urban development systems) and serving state and public interests in the implementation of urban development. The variety of managerial tasks within the indicated systems activity puts forward specific requirements for such informational systems.

Managerial informational systems should open up new opportunities in serving state and public interests in the implementation of urban development through the use of system analysis and management methods and modern computer technology. Thus, the most important substantive component of the proposed scientific concept is the substantiation of the possibility of practical use of informational systems adapted to modern state mechanisms for regulating socio-economic systems, which researchers now call "system regulators" to provide for state and public interests in urban development.

The above-mentioned system regulators organize the interaction of urban development entities in a spatial environment and reflect the system of urban development tools, focusing on mutual taking into account and coordinated realization of public interests and economic and business interests of urban development entities that carry out urban development and spatial development of the territory.

The expansion of urban planning regulation procedures and the introduction of informational systems in urban planning activities makes it possible to formulate a theoretical concept for research of serving state and public interests in urban development in the form of an informational and technological system for urban planning systems regulation, harmonizing the efforts of state and municipal government authorities and urban development entities into a single whole towards the im- plementation of design solutions of urban (territorial) planning documentation.

There are relatively few modern scientific and theoretical developments dedicated to the features and systematization of purposes, the content of developmental tasks and informational content of urban planning documentation in the Ukrainian urban planning practice. However, the breadth of comprehension, definitions, terms and methods of urban (territorial) planning and design vision allows to interpret the term "urban planning documentation" in terms of different contents and forms of graphic expression, which is reflected in the current tendencies in the formation of a system of urban planning documents.

Urban planning documentation is a key link in the formalization of urban planning design decisions in the public administration system. The system of urban planning documents is established by the urban planning legislation of Ukraine. As a rule, urban planning documents are spelled out in the legislation, up to the level of the master plan of the city, providing the government and local authorities at lower levels with the opportunity to choose and combine several different types of urban planning project documents. The search for a new mode of action for urban development subjects in the context of socio-economic transformation in our country makes it necessary to clarify the meaning and significance of urban planning documents, to provide urban planning activities with the necessary documents, to create informational and legal conditions for independent but controlled development of urban planning systems, which will make it possible to balance the problem of serving state and public interests in the implementation of urban development.

The main problem of the formation of a modern urban development documentation system is the immediate tendency of the functional-spatial and planning regulation of urban planning systems, in the development of the territory with the help of special tools, territorial indicators, and urban planning regulation standards. The updated documents, in our opinion, should meet the new conditions for the spatial development of the territory - regu- 
lation of socio-economic processes and the architectural and planning organization of urban planning systems with the help of urban development, including legal regulation of relations between subjects of urban development.

Therefore, the methodology of building a modern IT environment for urban development, informational systems and banks of urban development profile data (databases) is gaining importance. The effectiveness of the latter is proved by international experience, although in Ukraine they are not widely used [1]. At present, in the Ukrainian urban planning activities, informational systems are used more actively, unlike urban planning databanks [2].

Due to informational systems, specialists have the opportunity to see, assess, take into account the modern processes of development of the territory and create the basis for its sustainable spatial development. Information technology has become an integral part of urban development, being its new organizing and optimizing element that increases its overall effectiveness [3]. A special place in urban development is given to geographical and informational technologies (GIS) (Fig.1).

Their main functions are to create an urban development informational environment, to store territorial cartographical (spatial) information [4].

With GIS, it is possible not only to localize the spatial position of urban buildings with maximum coordinate accuracy, but also to "attach" them to information (to generate spatial data), conduct natural and landscape zoning on a geographical basis that is updated (adjusted) to the current time, and connect heterogeneous information [5].

The events of the last decade and the analysis of foreign experience of urban development suggest that the use of GIS urban development is a method of constructing the urban development informational environment [6, 7, 8]. The outlined method reflects the directions of sustainable spatial development of the territory, as well as the problems and imbalances in its organization, the socio-economic and spatial effectiveness of the regulated territorial indicators of changes in urban planning systems condition, the direction of information
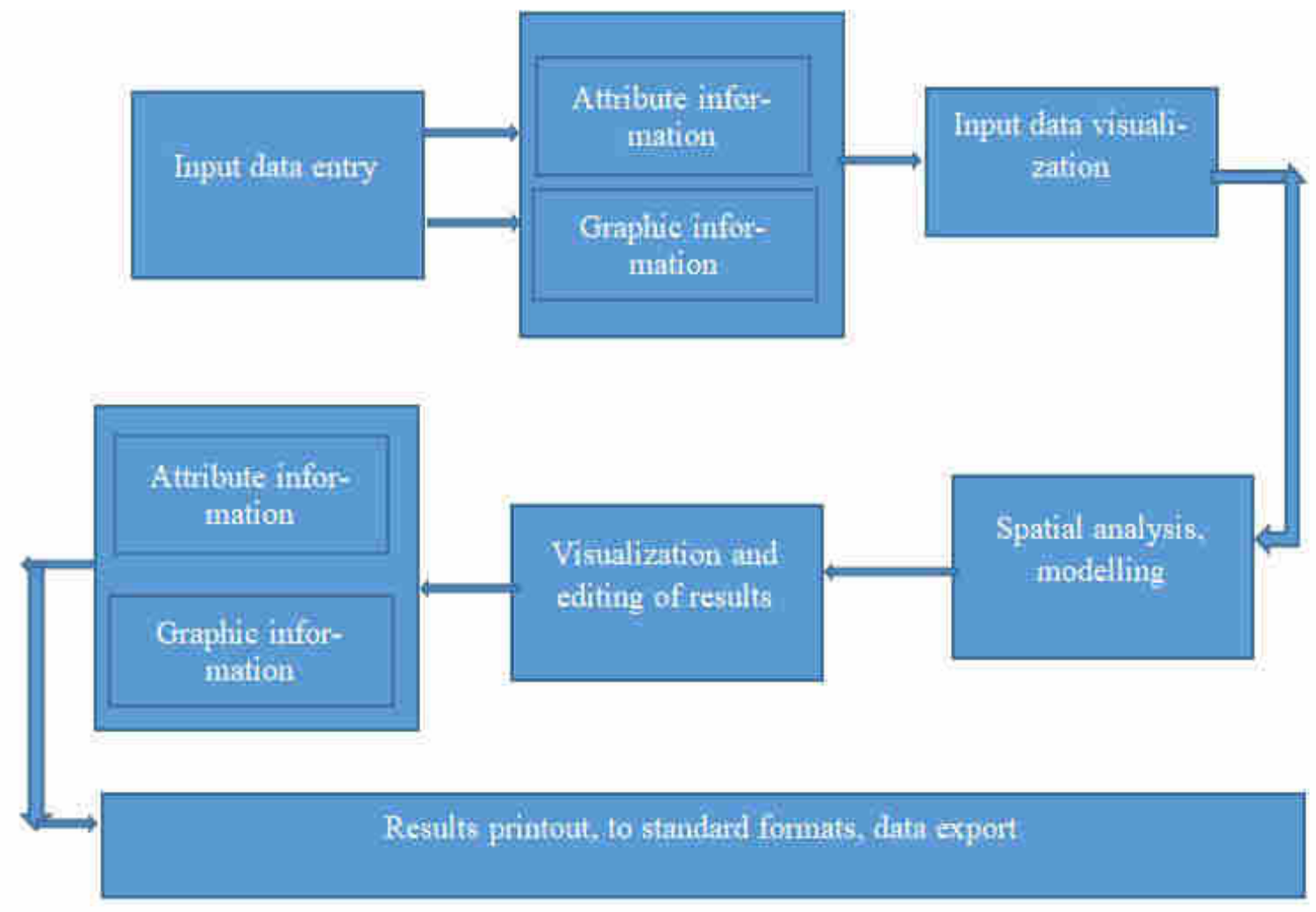

Fig. 1. Generalized scheme of GIS functioning 
flows in accordance with the tasks of managing urban development activities $[9,10]$. However, the use of this method provides a balance of state and public interests in the implementation of urban development.

The essence of the method is to improve the structure and quality of the input data for the purposes of the architectural organization of urban planning systems, the development of project documentation, decision-making on real estate management and informing the population, as well as the convenience of conducting the territory analysis [11].

The use of GITs in urban development involves their specific complex structural application. The informational structure of any urban planning profile GIT is formed on the basis of informational and technological blocks, thematic layers and informational layers of graphic (cartographic) information, data banks and databases. [12].

In modern practice, the most important are such technologies in urban development activities, the types of which can be defined as multifunctional territorial urban planning GISs (territorial GIS and urban planning GIS) and local territorial urban planning GIS. They differ in the quality and thematic focus of the graphic (cartographic) layers of information attached to them and independent data banks and databases [13].

In territorial GISs, which use results is evaluated by real socio-economic and territorial and spatial characteristics and indicators as objective data for making managerial and urban planning decisions, The following IT blocks are distinguished:

- geographical [11];

- administrative and territorial objects [14];

- spatial planning scheme [15];

- natural and ecological [16];

- engineering and infrastructural [17];

- law documents [18];

- the results of monitoring the implementation of documentation of urban (territorial) planning [14].

In large territorial GIS, these blocks form a fixed core. The IT blocks describe and characterize the main indicators and characteristics of the structural and infrastructural organization of the territory [19]. The content of thematic layers is coordinated not only with the peculiarities of building the structure of the territory [10], but also the complex tasks of managing its development [20].

\section{CONCLUSIONS AND RECOMMENDATIONS}

The problem of information support is one of the most important in urban development [3]. In the process of preparing and executing urban development projects, the decision maker has to deal with huge arrays of cartographic material, statistical, economical and other indicators. The tasks of creating an optimal model and urban planning project have been stretched for years: the cost of the mistake was very high. Significant cost of time, money, resources limited the number of alternatives, caused some superficiality of decisions and lack of calculations of project details. Geological and informational system is the contemporary computer technology making it possible to combine a model image of the territory (electronic display of maps, diagrams, aerial and orbital surveys) with table datatype (a variety of statistics, lists, economic indicators, etc.). A geographical and informational system also refers to a spatial data management system and attributes associated with them. More specifically, it is a computer system enabling the use, storing, editing, analysing and displaying of geographical data. Geographical and informational technologies (GIT) are the technological basis for creating geographical and informational systems to make them realize their functional capabilities. In the field of urban development, new GITs that provide promptness, completeness and reliability of information both about the existing condition of the urban environment within a particular urban area and about proposed measures for its change during development and reconstruction are of the greatest interest. The main purpose of the use of geographical and informational systems is to provide state authorities and local self-government with relevant, reliable and extensive information for comprehensive operational research, assessment and justification 
of managerial decisions aimed at creating a high-quality environment and life of the population in the city, protecting the environment and its sustainable development. The solution to these problems is based on the analysis of various multidimensional information and mathematical methods of modelling and forecasting the scenario of the city development.

The use of outlined technologies in the process of serving state and public interests will allow to achieve a number of constructive decisions in urban planning activities, including:

1. When planning and developing the urban territory, public interests will be taken into account by identifying the needs of the territorial community in existing and promising areas necessary for the placement and safe operation of housing and utilities infrastructure, of social, engineering and transport infrastructure, and solving other tasks to ensure sustainable urban development.

2. Individuals and legal entities will be provided with equal opportunities to acquire ownership or use of land for urban development on the basis of the comprehensive implementation of competitive principles, and the receipt of appropriate land at public auctions and tenders.

3. Land plots for urban planning needs will be provided in accordance with the General Plan of the city and other officially published urban planning documentation, which, in cases expressly provided for by the legislation of Ukraine or the decisions of local authorities, passed a public hearing or a survey among members of the territorial community of a city, region, micro district, district or other territorial unit.

4. Before making official decisions on the implementation of urban development, the executive body of the city council (city state administration) should:

- inform members of the Kyiv City Territorial Community residing in the territory of the urban development project on the planned urban development measures through the mass media or otherwise.

- formally inform deputies of city council about preparation and consideration of draft decisions on implementation of urban development in their constituencies.

- provide an opportunity for discussion of urban development projects in local selfgovernment bodies, etc.

\section{REFERENCES}

1. Ailykova H.V., 2013. Metodolohycheskye voprosы prymenenyia HYS-tekhnolohyi v systemakh hradostroytelnoho kadastra. Uch. zap. Tavrych. nats. un-ta. Ser. Heohrafyia, Vol.26, No.1, 3-11 (in Russian).

2. Biletskyi B.O., 2006. Deiaki aspekty intehratsii HIS-dodatkiv dlia system pidtrymky pryiniattia rishen. Materialy VI mizhnar. nauk-prakt. konf. HIS-forum.2006'. Kyiv, 235-238 (in Ukrainian).

3. Berehovskykh A.N., 2009. Kompleksnыi ynfrastrukturnыi podkhod $\mathrm{k}$ upravlenyiu razvytyem terrytoryi y prostranstvennыe dannыe. Upravlenye razvytyem terrytoryy, No.4, 9-14 (in Russian).

4. Khaskold V., 1991. Vvedenye v horodskye heohrafycheskye ynformatsyonnыe systemы. Oxford University Press, 321 (in Russian).

5. Tserklevych N.L., 2009. Problemy vedennia kadastru nerukhomosti na terytorii mist. KhIV Mizhnar. nauk.-tekhn. sympozium Heoinformatsiinyi monitorynh navkolyshnoho seredovyshcha: GPS i GIS-tekhnolohii (Alushta, Krym, 3-13 veresnia 2009). Alushta: Lvivska politekhnika, 206-213 (in Ukrainian).

6. Liashchenko A.A., 2013. Systemni vymohy do suchasnoho mistobudivnoho kadastru ta mistobudivnoi dokumentatsii. Mistobuduvannia ta terytorialne planuvannia, Vol.47, 397-405 (in Ukrainian).

7. Shypulin V.D., 2009. Planuvannia i upravlinnia HIS-proektamy: navch. Posibnyk. Kherson: KhNAMH, KhNURE, 2009, 158.

8. Iryna Ustinova, 2018. Hradostroytelnыe aspektы teoryy ustoichyvosty эkolohohradostroytelnыkh system. Transfer of Innovative Technologies. Vol.1, No.1. 5-16.

9. GIS Solutions for Urban and Regional Planning. Mode of access http://www.esri.com/library/ brochures/pdfs/gis-sols-for-urban-planning.pdf

10. INSPIRE Metadata Implementing Rules: Technical Guidelines based on EN ISO 19115 and EN ISO 19119. Drafting Team Metadata and European Commission Joint Research. Mode of access. http://inspire. 
jrc.ec.europa.eu/reports/Implementing-Rules/ metadata/ MD_IR_and_ISO_20090218.pdf.

11. Hokhman V.V., 2009. Obshchehorodskye HYS: chast 1. Arcreview. No. 3 (46), 2-3 (in Russian).

12. Karpinskyi Yu.O., 2006. Stratehiia formuvannia natsionalnoi infrastruktury heoprostorovykh danykh $\mathrm{v}$ Ukraini. Kyiv, NDIHK, 108 (in Ukrainian).

13. Mishchenko O.D., 2009. Multyahentni tekhnolohii yak osnova dlia upravlinnia mistobudivnymy systemamy. Mistobuduvannia ta terytorialne planuvannia: nauk.-tekhn. zb. Kyiv, KNUBA, Vol.33, 234-244 (in Ukrainian).

14. Svitlychnyi O.O., 2008. Osnovy heoinformatyky: Navchalnyi posibnyk. Sumy, VTD Universytetska knyha, 294 (in Ukrainian).

15. Seredynyn E.S., 2009. Munytsypalnыe HYS Ukraynd. Arcreview. No. 4(51), 7-9.

16. Domin M.M., 2009. Aktualni problemy teorii ta metodolohii mistobudivnykh doslidzhen. Mistobuduvannia ta terytorialne planuvannia: nauk.-tekhn. zb. Kyiv, KNUBA. Vyp.33, 141155 (in Ukrainian).

17. Tserklevych N.L., 2009. Problemy vedennia kadastru nerukhomosti na terytorii mist. KhIV Mizhnar. nauk.-tekhn. sympozium Heoinformatsiinyi monitorynh navkolyshnoho seredovyshcha: GPS i GIS-tekhnolohii (Alushta, Krym, 3-13 veresnia 2009). Alushta, Lvivska politekhnika, 206-213 (in Ukrainian).

18. Rozporiadzhennia Kabinetu Ministriv Ukrainy, 2010. Pro skhvalennia kontseptsii rozvytku elektronnoho uriaduvannia $\mathrm{v}$ Ukraini vid 13 hrudnia 2010 (in Ukrainian).

19.Rudenko L.H., 1994. Osnovy kontseptsii bahatotsilovoi HIS Ukrainy. Ukrainskyi heohrafichnyi zhurnal, No.3, 22-34 (in Ukrainian).

20. Planall Project Interoperability for Spatial Planning, 2011. Mauro Salvemini, Franco Vico, Corrado Iannucci (Editors), Planall Consortium, 210.

\section{Применение геонформационных систем при обеспечении государственных и обще- ственных интересов при осуществлении градостроительной деятельности}

\section{Евгений Клюшниченко, Ирина Савчук}

Аннотация. В статье резюмировано, что основная проблема формирования современной системы документации градостроительной деятельности заключается в непосредственной тенденций функционально-пространственного и планировочного регулирования градостроительных систем, в освоении территории с помощью специальных инструментов, территориальных показателей, нормативов градостроительного регулирования. Тогда как обновленные же документы должны удовлетворять новые условия пространственного развития территории - регулирование с помощью градостроительной деятельности социальноэкономических процессов и архитектурнопланировочной организации градостроительных систем, включая нормативно-правовое регулирование отношений субъектов градостроительной деятельности.

Целью исследования является анализ состояния и перспектив использования геоинформационных систем в градостроительстве. Для достижения цели применен ряд методов научного познания, в частности: анализ, синтез, обобщение, резюмирование и тому подобное. Расширение информационного содержания градостроительной деятельности является тенденцией, которая характеризует каждый этап ее развития. В современных социальноэкономических условиях тенденция превратилась в закономерность, которая в совокупности с управляющим (регулирующим) аспектом современного содержания градостроительной деятельности и совершенствованием правовых отношений субъектов градостроительной деятельности определяет сущность текущего этапа градостроительства.

На современном этапе отечественной градостоительной деятельности информационные системы используются более активно в отличие от градостроительных банков данных. Резюмировано, что благодаря информационным системам специалисты имеют возможность увидеть, оценить, учесть современные процессы освоения территории и создать основу для ее устойчивого пространственного развития. Информационные технологии стали неотъемлемой частью градостроительной деятельности, внесли в нее новое организующее и оптимизирующее начало, повысив в целом ее эффективность. Особое место в градостроительной деятельности отводится геоинформационным системам (ГИС). Их основные функции заключаются в создании информационной среды градостроительной деятельности, хранении территориальной картографической (пространственной) информации. 
Сделан вывод о том, что использование ГИС в градостроительной деятельности предполагает их специфическое комплексное структурное применения. Информационная структура любой ГИС градостроительного профиля формируется на основе информационно-технологических блоков, тематических слоев и информационных слоев графической (картографической) информации, банков и баз данных.

Ключевые слова: градостроительство, системы документации градостроительной деятельности, информационные системы, геоинформационные системы. 